\title{
Effect of Nitrogen Fertilization and Foliar Application with Iron Plus Molybdenum on Quality Parameters and Chemical Composition of Jews Mallow Plant (Corchorus olitorius L.) \\ Dina A. Ghazi \\ Soils Department, Faulty of Agriculture, Mansoura University, Mansoura, Egypt.
}

E-mail: dinaghazi3@gmail.com.

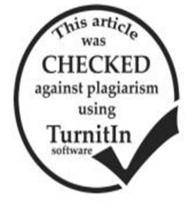

\begin{abstract}
A field experiment was carried out at the Experimental Farm, Faculty of Agricultural, Mansoura University, Dakahlia Governorate, Egypt in 2015/2016 season to estimate response of Jews mallow plant (Corchorus olitorius L.) cv. Balady to nitrogen (N) fertilizer and foliar spraying with Fe plus Mo. Nitrogen was applied in five rates $(0,50,100,125$ and $150 \%)$ as $\mathrm{NH}_{4} \mathrm{NO}_{3}(33.5 \% \mathrm{~N})$ from recommended dose (RD) in the presence and absence of iron $(\mathrm{Fe})$ plus molybdenum $(\mathrm{Mo})$ as a foliar way, at the rates of 250 and $75 \mathrm{mg} \mathrm{L}^{-1} \mathrm{Fe}$ and Mo, respectively on vegetative growth parameters, chemical composition and quality parameters for Jews mallow plant. A completely randomized block design was used, with 10 treatments with three replicates. According to results, vegetative growth parameters, chlorophyll a, b and total, vitamin $\mathrm{C}$, total carbohydrates and concentration of $\mathrm{P}, \mathrm{K}, \mathrm{Fe}$ and Mo in Jews mallow leaves plant increased significantly with increasing nitrogen fertilization rate up to $100 \%$ from recommended dose (RD) at marketing stage. With

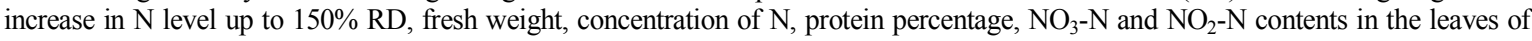
Jews mallow plant were significantly increased. On the different of this tendency; nitrate reductase enzyme activity (NRAA), vitamin C and total carbohydrates were significantly decreased with increasing nitrogen fertilizer rates from 100 to $150 \%$ RD in the leaves of Jews mallow plant. Also, results showed that foliar spraying with iron (Fe) plus molybdenum (Mo) in 50, 100, 125 and $150 \% \mathrm{~N}$ from recommended dose significantly improved vegetative growth parameters, quality parameters and chemical composition, in Jews mallow leaves. Analysis of $\mathrm{NO}_{3}-\mathrm{N}$ and $\mathrm{NO}_{2}-\mathrm{N}$ contents in leaves revealed that $\mathrm{NO}_{3}-\mathrm{N}$ and $\mathrm{NO}_{2}-\mathrm{N}$ concentrations decreases while nitrate reductase enzyme activity (NRAA) was more pronounced increases in the presence of foliar spraying with iron (Fe) plus molybdenum (Mo) with all levels of $\mathrm{N}$ fertilization. Moreover, it is concluded that iron plus molybdenum at the rate of 250 and $75 \mathrm{mg} \mathrm{L}^{-1}$ under $100 \%$ $\mathrm{N}$ from recommended dose increases vegetative growth parameters, quality parameters and chemical composition (except for $\mathrm{NO}_{3}-\mathrm{N}$ and $\mathrm{NO}_{2}-\mathrm{N}$ contents) in Jews mallow leaves. Thus protecting human health from the risk of accumulation of nitrates.
\end{abstract}

Keywords: Jews mallow; $\mathrm{N}$ fertilization; iron and molybdenum spraying; Nitrate and nitrite accumulation.

\section{INTRODUCTION}

Jews mallow (Corchorus olitorius L.) is an important indigenous leafy vegetable in many countries, including Egypt (Samra et al., 2007). Jews mallow play an important role in household food security and nutrition which has varying proportion of protein required for health and dietary fibre (Tovihoudji et al., 2015). It contains antioxidative phenolic compounds, vitamins B1, B2, C and $\mathrm{E}$, abundant $\beta$ - carotene, and minerals so; it is extremely consumed as a health vegetable.

Nitrogen is a macronutrient essential for the success of all known life forms, including grow crops and development. For this reason, nitrogen is the key factor limiting growth where play a vital role in plant performance in most agricultural systems. Nitrogen is a significant elemental in most of the biochemical reactions that compose life where it is a constituent of nucleic acids and proteins, in many of the vitamins and some of the plant growth regulators. The improvement of vegetative characteristics, this is attributed to nitrogen is a component in chlorophyll synthesis, hence it is a catalyst to support $\mathrm{CO}_{2}$ assimilation and photosynthesis required for facilitate and healthy growth. While, deficiency of nitrogen in soil resulted in reduced of the vegetative growth parameters of crops and hence stunted plants. Generally, the obtained data clearly showed that, Jute mallow (Corchorus olitorius L.) recorded a good response to the application of nitrogen fertilization, result in excessive vegetative growth, nutritional values and achieve higher yield and economic benefit (OguNRAinde and Fasinmirin, 2011).

Mahmoud et al., (2014) showed that Jews mallow (Corchorus olitorius L.) plant growth, as plant length, no. of leaves plant ${ }^{-1}$, dry and fresh weight of leaves (g). As well as dry and fresh weight of whole plant, yield as well as its leaf contents of the protein, N, P and $\mathrm{K}$ were higher in the order of application of $60>45>30 \mathrm{~kg} \mathrm{~N} \mathrm{fed}^{-1}$. Where, he found that with increasing N P K rates from 30 up to 90 units $\mathrm{fed}^{-1}$, the growth, yield and leaves contents of nutritional value of Jews mallow plant attributes were increased. These results are in agreement with those obtained by El-Ghamry, (2010) on rocket plant, Ahmadi et al., (2010), Islam et al., (2011) on radish plant, Aisha et al., (2013) on spinach plant and Mahlangu et al., (2016) on lettuce plant.

Ronaghi et al., (2002) pointed out that the $\mathrm{N}$ application increased $\mathrm{N}$ concentration and chlorophyll content. Also, they found that decreased of $\mathrm{Fe}$ concentration in spinach as a result of increased $\mathrm{N}$ application. The reason for this is the increase in plant biomass resulting from the dilution effect (Gulser 2005). El-Ghamry (2010) found that a significant decrease in values of $\mathrm{Fe}$ and $\mathrm{Mo}$ in rocket leaves due to increasing rates of $\mathrm{N}$ fertilization. Aisha et al (2013) found that the heaviest total leaves yield (ton $\mathrm{fed}^{-1}$ ) and its nutritional values, i.e. $\mathrm{N}, \mathrm{P}, \mathrm{K}$, protein and $\mathrm{NO}_{3}$ contents in leaf tissues were increased with addition of $70 \%$ of recommended rate (RR) of chemical fertilizer.

Spinach, lettuce, cabbage, radish, rocket and Jews mallow as a leafy vegetables need $\mathrm{N}$-fertilizers, so in Egypt, to be maintained green color of the foliage and enhancement the quality of crops without any care of the negative residual effect for this reason, large quantities of nitrogen fertilizer are consumed by farmers (Abd-Allah, 2001). If excessive $\mathrm{N}$ fertilizer had been applied to leafy vegetables, a large accumulation of nitrate concentration in the edible parts of these leafy plants occurs, therefore, there is damage to human health when consuming these plants. 
However, excessive amounts of nitrogen may cause some physiological disorders and some pathological problems. When nitrogen oversupply, it can lead to leaching of nitrate in the environment with negative effects on profitability, resource conservation, water pollution, a decrease in quality and human health due to nitrate accumulation. In the soil, nitrate ions usually complexes with amino compounds as the production of some pesticides degradation to produce carthenogenic substances that harm animals and human such as nitrosamine compounds. FAO (2000) a mounted $3.6 \mathrm{mg}$ for nitrate and $0.36 \mathrm{mg}$ for nitrite day $^{-1} \mathrm{~kg}^{-1}$ for human body as the critical level recommended. When $\mathrm{NO}_{3}$ is consumed a large amounts, we have to consider two problems the formation carthenogenic substances, in addition to that methaemoglobinaemia (blue baby syndrome) and stomach cancer. Hemoglobin molecule has the important function of transporting oxygen. Methaemoglobin is an oxidized form of haemoglobin. When more than $1 \%$ of hemoglobin is oxidized to methaemoglobin, in this case, methaemoglobin level is abnormally high thus the condition is known as methaemoglobinaemia. (Boink and Speijers, 2001). Nitrate itself in contrast to nitrite does not have the ability to transform haemoglobin into methaemoglobin. Nitrite oxidation of oxyhaemoglobin is reported according to the equation of Kosaka et al. (1979) as follows:

$4 \mathrm{HbO}_{2}+4 \mathrm{NO}_{2}^{-}+4 \mathrm{H}^{+}----4 \mathrm{Hb}^{+}+4 \mathrm{NO}_{3}^{-}+\mathrm{O}_{2}+2 \mathrm{H}_{2} \mathrm{O}$

( $\mathrm{HbO}_{2}$; Oxyhaemoglobin; Hb+; Methaemoglobin)

Therefore adequate $\mathrm{N}$ doses must be applied on Jews mallow at the right quantity to favour both growth and yield to avoid nitrate accumulation.

Concerning the effect of $\mathrm{Fe}$ and $\mathrm{Mo}$, micronutrients especially iron and molybdenum coupled with $\mathrm{N}$ levels were found to be achieving a positive effect on the vegetative growth parameters and yield of Jews mallow plant and its components and chemical composition of leaves compared to non-sprayed plant with all levels of $\mathrm{N}$ fertilization. But reduces $\mathrm{No}_{3}$ content compared to $\mathrm{N}$ application alone (Abd-Allah, 2001; El-Sawah et al., 2004; Salem, 2009).

El-Ghamry, (2010) who found that gradually and significantly increased for $\mathrm{No}_{3}{ }^{-1}$ and $\mathrm{NO}_{2}{ }^{-1}$ concentrations in the fresh leaves of rocket plant with increasing $\mathrm{N}$ fertilization levels from 0 up to $140 \mathrm{~kg} \mathrm{~N} \mathrm{ha}^{-1}$. In contrast, significantly decreased the activity of nitrate reductase enzyme with increasing nitrogen fertilization levels.

Therefore, the objective of this field study was to evaluate the effect of different rates of nitrogen fertilization and foliar spraying with $(\mathrm{Fe}+\mathrm{Mo})$ as on vegetative growth, chemical composition and quality parameters in the leaves of Jews mallow plant.

\section{MATERIALS AND METHODS}

A field study was set up at the experimental farm, Faculty of Agricultural, Mansoura University, Dakahlia Governorate, Egypt in growing season of 2015/2016. This present research aimed to evaluate the effect of different rates of nitrogen fertilization and foliar spraying with $(\mathrm{Fe}+$ Mo) on vegetative growth, chemical composition, quality parameters as well as $\mathrm{NO}_{3}-\mathrm{N}, \mathrm{NO}_{2}-\mathrm{N}$, nitrate reductase (NRA) enzyme activity in the leaves of Jews mallow plant (Corchorus olitorius L.) cv. Balady. The physico-chemical properties of soil showed that the soil of experimental site was clay loam in texture and poorly fertile soil. Some physico-chemical properties of the studied soil have been presented in Table 1.

Table 1. Some physico-chemical properties of the soils collected from the experimental field.

\begin{tabular}{lcc}
\hline Soil Properties & \multicolumn{1}{c}{ Method use } \\
\hline A: Particle size distribution & $\mathbf{2 0 1 5 / 2 0 1 6}$ & \\
\hline Property & 2.77 & \\
\hline Coarse Sand (\%) & 21.95 & The international pipette method Piper, (1950) \\
Fine Sand (\%) & \\
Silt (\%) & 47.11 & \\
Clay (\%) & 28.17 & \\
Texture class & Clay Loam & \\
\hline B: Chemical properties & & Method adopted \\
\hline Analysis & Values & pH meter (Jackson, 1967) \\
Soil pH (1:2.5) & 8.05 & Electrical conductivity meter at 25 ${ }^{\circ} \mathrm{C}$ (Jackson, 1967) \\
Electrical conductivity (dS m $\left.{ }^{-1}\right)(1: 5)$ & 0.93 & Walkley and Black method (Black, 1965) \\
O.M (\%) & 1.51 & Collin's calcimeter (Piper, 1950) \\
CaCO $(\%)$ & 3.87 & \\
C: Available macro and micro nutrient (mg kg $\left.{ }^{-1}\right)$ & \\
$\mathrm{N}$ & 41.96 & The conventional method of Kjeldahl (Bremner and Mulvany 1982) \\
$\mathrm{P}$ & 4.75 & Spectrophotometer (Olsen and Sommers 1982) \\
$\mathrm{K}$ & 177.9 & Flame photometer (Black, 1965) \\
Fe & 1.98 & DTPA extractable method (Lindsay and Norvel 1978) \\
Mo & 0.53 & \\
\hline
\end{tabular}

A completely randomized block design was used, with 10 treatments with three replicates to estimate the effect of different levels of $\mathrm{N}$-fertilization; 0, 50, 100, 125 and $150 \%$ as $\mathrm{NH}_{4} \quad \mathrm{NO}_{3} \quad(33.5 \% \quad \mathrm{~N})$ from the recommended dose $(\mathrm{RD})$ according to the Ministry of
Agriculture and Soil Reclamation (MASR), $60 \mathrm{~kg} \mathrm{~N}$ fed $^{-1}$ in the presence and absence of $(\mathrm{Fe}+\mathrm{Mo})$ as a foliar way, Fe-EDTA at the rate of $250 \mathrm{mg} \mathrm{L}^{-1}$ and $\mathrm{Mo}$ as Ammonium molybdate at the rate of $75 \mathrm{mg} \mathrm{L}^{-1}$. 
Description of $\mathbf{N}$ treatments

\begin{tabular}{lccc}
\hline Code & N Treatments & Code & N Treatments \\
\hline T1 & Zero N-fertilization as Control & T6 & $100 \%$ mineral nitrogen $(\mathrm{N})+(\mathrm{Fe}+\mathrm{Mo})$ \\
T2 & Foliar spraying with Fe $250 \mathrm{mg} \mathrm{L}^{-1}+\mathrm{Mo} 75 \mathrm{mg} \mathrm{L}^{-1}$ & $\mathrm{~T} 7$ & $125 \%$ mineral nitrogen $(\mathrm{N})$ from recommended dose $(\mathrm{RD})$ \\
$\mathrm{T} 3$ & $50 \%$ mineral nitrogen $(\mathrm{N})$ from recommended dose $(\mathrm{RD})$ & $\mathrm{T} 8$ & $125 \%$ mineral nitrogen $(\mathrm{N})+(\mathrm{Fe}+\mathrm{Mo})$ \\
T4 & $50 \%$ mineral nitrogen $(\mathrm{N})+(\mathrm{Fe}+\mathrm{Mo})$ & $\mathrm{T} 9$ & $150 \%$ mineral nitrogen $(\mathrm{N})$ from recommended dose $(\mathrm{RD})$ \\
$\mathrm{T} 5$ & $100 \%$ mineral nitrogen $(\mathrm{N})$ from recommended dose $(\mathrm{RD})$ & $\mathrm{T} 10$ & $150 \%$ mineral nitrogen $(\mathrm{N})+(\mathrm{Fe}+\mathrm{Mo})$ \\
\hline
\end{tabular}

The $\mathrm{N}$ fertilizer is applied in two equal doses; one after 21 days from sowing and the second 15 days later. Foliar applications of Fe plus Mo were done at the same time of nitrogen fertilizer addition. All the other cultivation processes according to (MASR).

Plants of six meters square were build-up. Each plot consisted (3 m in length $x 40 \mathrm{~cm}$ in width) included 5 rows. Jews mallow seeds cv. Balady were planted on $30^{\text {th }}$ of March; 2016 season in hills; $15 \mathrm{~cm}$ apart on both sides of rows. Jews mallow was thinned to 3 plants per hill after two 21 days from sowing.

At 60 days after sowing of Jews mallow, 20 plants were taken at random from every plot. plant growth parameters; plant length $(\mathrm{cm})$, no. of leaves plant ${ }^{-1}$, dry and fresh weight $\left(\mathrm{g}\right.$ plant $\left.^{-1}\right)$, total yield ton fed ${ }^{-1}$, chlorophyll contents (mg. $\mathrm{g}^{-1}$ ) and then, nitrate, nitrite contents, nitrate reductase enzyme activity, protein, vitamin $\mathrm{C}$, and total carbohydrates percentage were measured. Samples were oven dried, then chemical composition in leaves of jews mallow plant $\mathrm{N}, \mathrm{P}$ and $\mathrm{K}$ as well as Fe and $\mathrm{Mo}\left(\mathrm{mg} \mathrm{kg}^{-1}\right)$ were estimated.

Jews mallow Leaves were oven dried at $70{ }^{0} \mathrm{C}$ for $72 \mathrm{~h}$ to constant weight after 60 days (harvest stage) from planting, then wet digested by using $\mathrm{H}_{2} \mathrm{SO}_{4}$ and $\mathrm{HCLO}_{4}$ acid as described by Peterburgski, (1986). The total NPK were determined in Jews mallow leaves using the following methods: total nitrogen (\%) using microKjeldahl, phosphorus (\%) was determined calorimetrically and potassium (\%) using a flame photometer by Jackson (1967), respectively.

Total iron and molybdenum were measured in aqua regia digestion, the procedure recommended by the International Organization for Standardization (ISO) (1995). Metals content in digested solution were estimated using atomic absorption spectrophotometer (AAS).

Nitrate and nitrite were measured by using a rapid method of Singh (1988). Nitrate reductase enzyme activity described by Hageman and reed, (1980).
Protein content $(\%)$ was determined in the dry leaves by determination of $\mathrm{N} \%$ and was multiplied in 5.75 according to AOAC (2007).

Percentage of total carbohydrates and vitamin C were determined using the method described by Dubois et al., (1956) and Mazumdar and Majumder (2003), respectivelly.

Chlorophyll contents were determined according to the method of Sadasivam and Manickam (1996).

\section{Statistical Analysis:}

In this current study, the collected data were analyzed using the statistical analysis by means of COSTATE software program according to the method described by (Gomez and Gomez 1984)

\section{RESULTS AND DISCUSSION}

\section{Plant Growth Parameters}

The effect of different rates of $\mathrm{N}$ fertilization and $\mathrm{Fe}$ + Mo combined together as foliar spraying on plant length $(\mathrm{cm})$, number of leaves plant ${ }^{-1}$, dry and fresh weight $(\mathrm{g}$ plant $^{-1}$ ), and total yield ton fed ${ }^{-1}$ for Jews mallow plant at marketing stage were shown in Table 2. It can be observed that; an application of $\mathrm{N}$-fertilization levels studied affected in single form or combined with Fe plus Mo in foliar way showed a positive effect on all vegetative growth parameters compared with the control treatment. The average values of all vegetative growth parameters under present study (except for fresh weight $\mathrm{g} \mathrm{plan}^{-1}$ ) were significantly increased with increasing levels of $\mathrm{N}$ fertilization from 50 to $100 \% \mathrm{RD}$ in single form over the control treatment. While, these average values were significantly decreased with increasing the level of $\mathrm{N}$ fertilization from 100 to 125 or $150 \% \mathrm{RD}$ in single form. Increasing the rate of $\mathrm{N}$-fertilization from 50 to $150 \% \mathrm{RD}$ in single form was led to significantly increase in the average values of fresh weight $\mathrm{g} \mathrm{plan}^{-1}$.

Table 2. Effect of different levels of $\mathrm{N}$-fertilization, $\mathrm{Fe}+\mathrm{Mo}$ as foliar way on plant length (cm), no. of leaves plant ${ }^{-1}$, dry and fresh weight $\left(\mathrm{g}\right.$ plant $^{-1}$ ), and total yield ton fed $^{-1}$ of Jews mallow plant during 2015/2016 season.

\begin{tabular}{|c|c|c|c|c|c|}
\hline Treatments & $\begin{array}{c}\text { Plant Length } \\
\text { (cm) }\end{array}$ & $\begin{array}{l}\text { No. of } \\
\text { leaves plant }\end{array}$ & $\begin{array}{c}\text { Fresh Weight } \\
\text { g plant }^{-}\end{array}$ & $\begin{array}{l}\text { Dry Weight } \\
\text { g plant }^{-1}\end{array}$ & $\begin{array}{l}\text { Yield } \\
\text { ton fed }^{-1}\end{array}$ \\
\hline Control & $28.33 \pm 1.15$ & $22.00 \pm 2.00$ & $24.71 \pm 0.67$ & $6.77 \pm 0.25$ & $8.96 \pm 0.29$ \\
\hline $\mathrm{Fe}+\mathrm{Mo}$ & $29.00 \pm 2.00$ & $23.00 \pm 2.00$ & $25.74 \pm 0.29$ & $7.18 \pm 0.32$ & $9.22 \pm 0.27$ \\
\hline $50 \% \mathrm{~N}$ & $30.33 \pm 1.15$ & $24.00 \pm 2.00$ & $26.81 \pm 0.32$ & $7.60 \pm 0.29$ & $9.72 \pm 0.21$ \\
\hline $50 \% \mathrm{~N}+(\mathrm{Fe}+\mathrm{Mo})$ & $34.33 \pm 1.15$ & $28.00 \pm 2.00$ & $27.82 \pm 0.39$ & $9.50 \pm 0.25$ & $10.88 \pm .29$ \\
\hline $100 \% \mathrm{~N}$ & $32.66 \pm 1.15$ & $27.00 \pm 2.00$ & $28.91 \pm 0.38$ & $9.05 \pm 0.35$ & $10.62 \pm 0.23$ \\
\hline $100 \% \mathrm{~N}+(\mathrm{Fe}+\mathrm{Mo})$ & $37.33 \pm 1.15$ & $30.00 \pm 2.00$ & $31.90 \pm 0.42$ & $10.83 \pm 0.30$ & $11.69 \pm 0.26$ \\
\hline $125 \% \mathrm{~N}$ & $32.00 \pm 2.00$ & $25.00 \pm 2.00$ & $29.79 \pm 0.32$ & $8.56 \pm 0.33$ & $10.32 \pm 0.14$ \\
\hline $125 \% \mathrm{~N}+(\mathrm{Fe}+\mathrm{Mo})$ & $36.66 \pm 1.15$ & $28.33 \pm 3.05$ & $32.93 \pm 0.39$ & $10.36 \pm 0.38$ & $11.43 \pm 0.21$ \\
\hline $150 \% \mathrm{~N}$ & $30.66 \pm 1.15$ & $24.33 \pm 3.05$ & $30.86 \pm 0.38$ & $8.13 \pm 0.35$ & $10.02 \pm 0.22$ \\
\hline $150 \% \mathrm{~N}+(\mathrm{Fe}+\mathrm{Mo})$ & $36.00 \pm 2.00$ & $29.00 \pm 2.00$ & $33.99 \pm 0.35$ & $9.92 \pm 0.32$ & $11.24 \pm 0.19$ \\
\hline F.Test & $* *$ & $* *$ & $* *$ & $* *$ & $* *$ \\
\hline LSD at $5 \%$ & 1.2129 & 1.9999 & 0.3396 & 0.2736 & 0.2068 \\
\hline
\end{tabular}

\pm SD: standard deviation 
Table 2, shows foliar spraying with $\mathrm{Fe}+\mathrm{Mo}$ in combination with any levels of $\mathrm{N}$-fertilization was significantly increased the average values of all vegetative growth parameters as compared to the untreated plants. Results further revealed that the maximum plant height $(37.33 \mathrm{~cm})$, no. of leaves plant ${ }^{-1}(30.00)$, dry weight $(10.83$ g plant $\left.{ }^{-1}\right)$, and total yield (11.69 ton fed $^{-1}$ ) were found in $100 \% \mathrm{~N}$ and $\mathrm{Fe}+$ Mo treatment, which were 31.76, 36.36, 59.97 and $30.46 \%$ higher over the control, respectively

\section{Leaf chlorophyll contents}

As shown in Fig 1, the same trend of plant growth parameters was realized in chlorophyll contents in Jews mallow leaves. Results indicated that the maximum leaf chlorophyll $\mathrm{a}, \mathrm{b}$ and total chlorophyll were obtained for the treatment of $100 \% \mathrm{RD}$ and receiving foliar application of iron@250 mg L ${ }^{-1}$ and molybdenum@75 mg L ${ }^{-1}$. Plants fertilized with soil applied $\mathrm{N}$-fertilization rates at 125 and $150 \% \mathrm{RD}$ alone or combination with foliar spraying with $\mathrm{Fe}+$ Mo showed leaf chlorophyll a, b and total chlorophyll less than obtained from $100 \%$ RD. However, control treatment showed the lowest values for leaf chlorophyll a, $\mathrm{b}$ and total in Jews mallow leaves.

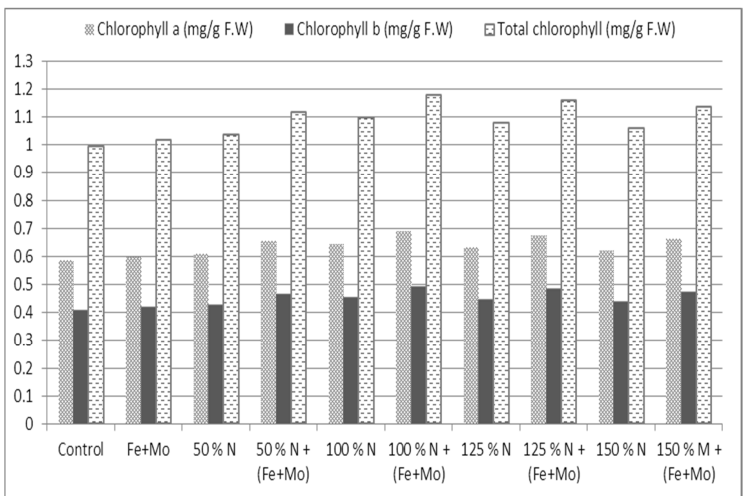

Fig. 1. Effect of different levels of N-fertilization, $\mathrm{Fe}$ plus Mo as foliar way on chlorophyll $a, b$ and total, in Jews mallow leaves plant.

Results of the previously mentioned traits can be explained on the basis of; the increases in vegetative growth parameters of Jews mallow plant as the applied nitrogen rate increased may be attributed to nitrogen is a significant elemental on producing more tissues and organs because it is stimulating the meristematic activity and constituent of proteins, many important substances of plant cell, nucleic acid (RNA and DNA), thus it is critical in improving growth and yield of vegetable crops. Also; this increase may be reconfirm the role of nitrogen fertilizer in promoting vegetative growth and impart the characteristics of deep green color to foliage because it is a component synthesis of chlorophyll which is essential for photosynthesis, functions of enzymes and metabolic processes depend on an adequate supply of mineral nutrients like nitrogen.

It was observed that $150 \% \mathrm{~N}$ of the recommended dose resulted in an increase in moisture in Jews mallow leaves. Therefore, there was a significant considerably increase in the average values of fresh weight for Jews mallow leaves with the level of $\mathrm{N}$ fertilization was increased. Similar results about different plants were reported by (Shaheen et al., 2012; Aisha et al., 2013; Mahmoud et al., 2014 and Abdelraouf 2016).

Data also indicated that foliar spraying with $\mathrm{Fe}+$ Mo together have been recorded a pronounced high effects on the average values of all previous parameters with all levels of $\mathrm{N}$ fertilization under present research. The appropriate role of $\mathrm{Fe}$ and $\mathrm{Mo}$ on stimulating plant bioactivities, biosynthesis of amino acids, protein, and chlorophyll resulting from enzymatic system as well as throughout improvement of the nutrient status. These results are agreement with (El-Agrodi et al., 2001; Salem, 2009; El-Ghamry, 2010; and EL-Aila et al., 2015). Iron is an important element in crops, because it is necessary for synthesization of chlorophyll, keeps up the structure of chloroplasts, involved in nitrogen fixations which lead to higher crop production and leaf area increase. Molybdenum stimulates growth, increases chlorophyll contents and yield of some green vegetable plants (Kheir et al., 1991). Also, lacking of molybdenum in plants creates some abnormal changes in plant chloroplast and causes reduce in chlorophyll contents. But on the other hand, Mo fertilizers of molybdenum when provided to the plant generally accelerate the photosynthetic activities and products of photosynthesis (Nasar and Shah 2017).

$\mathrm{N}, \mathrm{P}, \mathrm{K}(\%), \mathrm{Fe}, \mathrm{Mo}\left(\mathrm{mg} \mathrm{kg}^{-1}\right)$

With attention to results in Tables 3 and 4 showed different levels of $\mathrm{N}$-fertilizers effects, iron plus molybdenum as foliar application on $\mathrm{N}, \mathrm{P}, \mathrm{K}$, iron and molybdenum concentrations in the leaves of Jews mallow at marketing stage. Regarding rates of $\mathrm{N}$ fertilizers effects data show that different levels of nitrogen 50, 100, 125 and $150 \% \mathrm{RD}$ in single form resulted in significantly increase in $\mathrm{N}$ values in Jews mallow leaves which accounted to be $17.02,28.28,35.11$ and $44.40 \%$ for $\mathrm{N}$ over the control treatment, respectively. While such effect was realized for $\mathrm{P}, \mathrm{K}, \mathrm{Fe}$ and Mo contents tell the rate of $100 \% \mathrm{RD}$ in single form and then the contents of $\mathrm{P}, \mathrm{K}, \mathrm{Fe}$ and $\mathrm{Mo}$ in the dry matter of Jews mallow leaves were decreased as the rate of $\mathrm{N}$-fertilization was increased from $125 \%$ up to 150 $\%$ RD. These results are compatible with (Ahmed et al., 2002 and Gulser, 2005). Dilution effect leads to an increase in biomass due to increased nitrogen fertilization, which results in a decrease in micronutrient contents in leafy vegetables

Spraying iron and molybdenum with all levels of nitrogen fertilization led to a significant increase in the nitrogen concentration of Jews mallow leaves of nitrogen compared with the nitrogen content with the same nitrogen treatments without iron and molybdenum spraying. On the other hand; when soil applied $\mathrm{N}$-fertilization levels increased from 125 to $150 \%, \mathrm{P}, \mathrm{K}$, iron and molybdenum concentrations in Jews mallow leaves were decreased, the same trend was showed in the presence and absence of Fe plus Mo foliar spraying. While, the lowest values $\mathrm{N}$ concentration in Jews mallow leaves of were recorded for the control treatment. 
Table 3. Effect of different levels of $\mathrm{N}$-fertilization, $\mathrm{Fe}+\mathrm{Mo}$ as foliar way on nitrogen, phosphrous and potassium contents in Jews mallow leaves plant during 2015/2016 season.

\begin{tabular}{lccc}
\hline Treatments & $\mathbf{N} \%$ & $\mathbf{P} \%$ & $\mathbf{K} \%$ \\
\hline Control & $1.216 \pm 0.06$ & $0.228 \pm 0.004$ & $1.773 \pm 0.08$ \\
$\mathrm{Fe}+\mathrm{Mo}$ & $1.323 \pm 0.07$ & $0.239 \pm 0.009$ & $1.886 \pm 0.05$ \\
$50 \% \mathrm{~N}$ & $1.423 \pm 0.06$ & $0.247 \pm 0.008$ & $1.966 \pm 0.04$ \\
$50 \% \mathrm{~N}+(\mathrm{Fe}+\mathrm{Mo})$ & $1.880 \pm 0.03$ & $0.295 \pm 0.005$ & $2.323 \pm 0.09$ \\
$100 \% \mathrm{~N}$ & $1.560 \pm 0.04$ & $0.283 \pm 0.005$ & $2.216 \pm 0.04$ \\
$100 \% \mathrm{~N}+(\mathrm{Fe}+\mathrm{Mo})$ & $1.986 \pm 0.08$ & $0.319 \pm 0.003$ & $2.583 \pm 0.06$ \\
$125 \% \mathrm{~N}$ & $1.643 \pm 0.06$ & $0.270 \pm 0.004$ & $2.136 \pm 0.03$ \\
$125 \% \mathrm{~N}+(\mathrm{Fe}+\mathrm{Mo})$ & $2.110 \pm 0.03$ & $0.312 \pm 0.007$ & $2.496 \pm 0.05$ \\
$150 \% \mathrm{~N}$ & $1.756 \pm 0.07$ & $0.258 \pm 0.003$ & $2.043 \pm 0.10$ \\
$150 \% \mathrm{~N}+(\mathrm{Fe}+\mathrm{Mo})$ & $2.190 \pm 0.03$ & $0.304 \pm 0.008$ & $2.400 \pm 0.03$ \\
\hline F.Test & $* *$ & $* *$ & $*$ \\
LSD at 5\% & 0.0505 & 0.0044 & 0.0541 \\
\hline
\end{tabular}

The average values of iron plus molybdenum were significantly increased by increasing nitrogen fertilizer up to $150 \%$ RD (Table 4). As shown in Table 3 and 4, the results showed that increased concentrations of nitrogen, phosphorus, potassium, iron and molybdenum with all levels of nitrogen fertilization in the presence of iron plus molybdenum spray. These results are in harmony with those obtained by (Abd-Allah, 2001; El-Sawah et al., 2004; Salem, 2009; Ahmed et al., 2011).

EL-Aila et al., (2015) they stated that foliar spraying of iron plus molybdenum coupled with different levels of nitrogen fertilization on leafy vegetable, resulted in a significant increase of $\mathrm{N}, \mathrm{P}, \mathrm{K}$, iron and molybdenum concentrations in the leaves than those obtained due to applying the same $\mathrm{N}$ levels only. The reason is that spraying with $\mathrm{Fe}$ and Mo combined together at any $\mathrm{N}$ levels due to iron and molybdenum promoted vegetative growth parameters, yield, increased chlorophyll, its components and chemical composition of leaves, thus increased the respective nutrient contents in leaf tissues than those obtained due to applying the same $\mathrm{N}$ levels only.

Table 4. Effect of different levels of $\mathrm{N}$-fertilization, $\mathrm{Fe}+$ Mo as foliar way on iron and molybdenum contents in Jews mallow leaves plant during 2015/2016 season.

\begin{tabular}{lcc}
\hline Treatments & Iron (Fe) $\mathbf{~ g ~ k g}^{-\mathbf{1}}$ & Molybdenum (Mo) $\mathbf{~ m g ~ k g ~}^{-1}$ \\
\hline Control & $1.92 \pm 0.11$ & $1.14 \pm 0.11$ \\
$\mathrm{Fe}+\mathrm{Mo}$ & $2.55 \pm 0.25$ & $1.90 \pm 0.14$ \\
$50 \% \mathrm{~N}$ & $2.04 \pm 0.21$ & $1.30 \pm 0.13$ \\
$50 \% \mathrm{~N}+(\mathrm{Fe}+\mathrm{Mo})$ & $2.78 \pm 0.18$ & $2.18 \pm 0.13$ \\
$100 \% \mathrm{~N}$ & $2.16 \pm 0.17$ & $1.45 \pm 0.06$ \\
$100 \% \mathrm{~N}+(\mathrm{Fe}+\mathrm{Mo})$ & $2.98 \pm 0.14$ & $2.44 \pm 0.16$ \\
$125 \% \mathrm{~N}$ & $2.25 \pm 0.17$ & $1.60 \pm 0.15$ \\
$125 \% \mathrm{~N}+(\mathrm{Fe}+\mathrm{Mo})$ & $3.21 \pm 0.18$ & $2.65 \pm 0.15$ \\
$150 \% \mathrm{~N}$ & $2.37 \pm 0.16$ & $1.74 \pm 0.14$ \\
$150 \% \mathrm{~N}+(\mathrm{Fe}+\mathrm{Mo})$ & $3.41 \pm 0.15$ & $2.98 \pm 0.12$ \\
\hline F.Test & $* *$ & $* *$ \\
LSD at 5\% & 0.1561 & 0.1171 \\
\hline
\end{tabular}

Nitrate $\left(\mathrm{NO}_{3}-\mathrm{N}\right)$, nitrite $\left(\mathrm{NO}_{2}-\mathrm{N}\right)$, Nitrate Reductase Activity (NRA) and protein percentage

The perusal of data presented in Table 5 reveals that the average concentrations of $\mathrm{NO}_{3}-\mathrm{N}$ and $\mathrm{NO}_{2}-\mathrm{N}$ and nitrate reductase (NRA) activity in Jews mallow fresh leaves as influenced by soil $\mathrm{N}$-fertilization levels and foliarly applied of $\mathrm{Fe}+\mathrm{Mo}$ combined together at the market maturity. The investigation of the effects of soil nitrogen levels on $\mathrm{NO}_{3}-\mathrm{N}, \mathrm{NO}_{2}-\mathrm{N}$ concentrations showed that; with increasing $\mathrm{N}$ levels from 0 to $150 \% \mathrm{RD}$, the average concentrations of $\mathrm{NO}_{3}-\mathrm{N}$ and $\mathrm{NO}_{2}-\mathrm{N}$ were significantly increased. Plants treated with $150 \% \mathrm{~N}$ from the recommended dose recorded the highest $\mathrm{NO}_{3}-\mathrm{N}$ and $\mathrm{NO}_{2}-$ $\mathrm{N}$ accumulation in Jews mallow leaves $(580.23 \pm 7.84$ and $5.84 \pm 0.13 \mathrm{mg} \mathrm{kg}^{-1}$ F.W for nitrate and nitrite), respectively while this treatment recorded the lowest level of nitrate reductase (NRAA) activity. The lowest concentrations of nitrate and nitrite were in control plants. On the contrary of this trend, it was noted that there was a significant decrease in the nitrate reductase (NRA) enzyme activity ( $\mu \mathrm{mol} \mathrm{g}^{-1} \min ^{-1} \mathrm{NO}_{2}^{-} \mathrm{F} . \mathrm{W}$ ) with increasing nitrogen fertilization rates up to $150 \% \mathrm{RD}$. The $\mathrm{r}$ rates of decreasing were accounted to be $37.61 \%, 44.76 \%, 50.95 \%$ and $59.52 \%$ for the treatments of $50,100,125$ and $150 \%$, respectively.

These results may be explained on basis of; the excessive $\mathrm{N}$ fertilizer use may result in the accumulation of $\mathrm{NO}_{3}{ }^{-}$in the leafy vegetable leaves and reduce the quality of the vegetable (Liu et al., 2014; Qiu et al., 2014). The excess are absorbed rapidly into the plant leading to higher and accumulated nitrate/nitrite levels and stored predominantly in the green leafy part of the plant. Nitrate itself is relatively non-toxic; however, it may be produce $\mathrm{N}$-nitroso compounds resulting from nitrate transformed internally to nitrite, which can react with amines and amides thus produce carcinogenic substances that damage animals and human. These substances have been related to an increased risk of diseases, such as the 
methemoglobinemia and have been associated with chronic diseases such as leukaemia and gastrointestinal cancers Santamaria, (2006).

Regarding nitrogen fertilizer levels effects in the presence of foliar spraying with Fe plus Mo together in Table 5 found that; the concentrations of nitrate and nitrite in Jews mallow leaves significantly declined than those obtained for the plants treated with the same levels of nitrogen fertilization only. As for nitrate reductase (NRA) enzyme activity, foliar spraying with iron plus molybdenum was more pronounced increases in the levels of enzyme activity (NRA) with all rates of nitrogen fertilization compared with those obtained from the same rates of nitrogen fertilization in the absence of iron plus molybdenum in foliar way as shown in Table 5.

Iron foliar spraying has the beneficial and stimulation effect on the activity of nitrate and nitrite enzymes, so iron plays a vital role on decreasing the content of nitrate and nitrite in Jews mallow leaves plant.
Also, among the management practices used to reduce the $\mathrm{NO}_{3}{ }^{-}$accumulation in the leafy vegetables, the Mo application has been reported as an excellent alternative. This because the molybdenum involvement in the nitrogen fixation processes, transport of $\mathrm{N}$ compounds in plants and nitrate reduction thus it plays a significant role in nitrogen metabolism of plants. Thus, it is expected the application of Mo improves the $\mathrm{N}$ assimilation of plants, reducing the nitrate concentration in leaves and, consequently, improving the quality and commercial yield of leafy vegetables. So, the reduction of $\mathrm{NO}_{3}^{-}$concentration in the leaves of leafy vegetable with Mo foliar application occurred because this micronutrient plays an indispensable role in the $\mathrm{NO}_{3}{ }^{-}$assimilation taken up by plants (Resende et al., 2010 and Liu et al., 2014). These results are confirmed with those obtained by (Abd-Allah, 2001; Hammad et al., 2007; Salem, 2009; El-Ghamry, 2010 and Sakara, 2016).

Table 5. Effect of different levels of N-fertilization, Fe + Mo as foliar way on nitrate, nitrite (mg $\left.\mathrm{kg}^{-1}\right)$ and NRAA mg. min $^{-1} \cdot \mathrm{g}^{-1} \mathrm{~F}$.W contents in Jews mallow leaves plant during 2015/2016 season.

\begin{tabular}{|c|c|c|c|c|}
\hline Treatments & $\begin{array}{l}\mathrm{NO}_{3}-\mathrm{N} \\
\mathrm{mg} \mathrm{kg}^{-1}\end{array}$ & $\begin{array}{l}\mathrm{NO}_{2}-\mathrm{N} \\
\mathrm{mg} \mathrm{kg}^{-1}\end{array}$ & $\begin{array}{c}\text { *NRAA } \\
\left(\mu \mathrm{mol} \mathrm{g} \mathrm{g}^{-1} \min ^{-1} \mathrm{NO}_{2}\right) \mathrm{F} . \mathrm{W}\end{array}$ & $\begin{array}{c}\text { Protein } \\
\%\end{array}$ \\
\hline Control & $411.30 \pm 9.10$ & $4.10 \pm 0.08$ & $0.210 \pm 0.01$ & $6.99 \pm 0.35$ \\
\hline $\mathrm{Fe}+\mathrm{Mo}$ & $395.80 \pm 12.92$ & $3.94 \pm 0.09$ & $0.219 \pm 0.01$ & $7.61 \pm 0.40$ \\
\hline $50 \% \mathrm{~N}$ & $499.00 \pm 8.50$ & $5.12 \pm 0.08$ & $0.131 \pm 0.01$ & $8.18 \pm 0.35$ \\
\hline $50 \% \mathrm{~N}+(\mathrm{Fe}+\mathrm{Mo})$ & $435.03 \pm 7.92$ & $4.27 \pm 0.09$ & $0.188 \pm 0.02$ & $10.81 \pm 0.20$ \\
\hline $100 \% \mathrm{~N}$ & $525.73 \pm 8.43$ & $5.28 \pm 0.14$ & $0.116 \pm 0.01$ & $8.97 \pm 0.23$ \\
\hline $100 \% \mathrm{~N}+(\mathrm{Fe}+\mathrm{Mo})$ & $441.13 \pm 7.38$ & $4.44 \pm 0.11$ & $0.172 \pm 0.01$ & $11.42 \pm 0.46$ \\
\hline $125 \% \mathrm{~N}$ & $543.50 \pm 7.90$ & $5.48 \pm 0.08$ & $0.103 \pm 0.01$ & $9.45 \pm 0.34$ \\
\hline $125 \% \mathrm{~N}+(\mathrm{Fe}+\mathrm{Mo})$ & $457.76 \pm 5.10$ & $4.61 \pm 0.14$ & $0.159 \pm 0.01$ & $12.13 \pm 0.19$ \\
\hline $150 \% \mathrm{~N}$ & $580.23 \pm 7.84$ & $5.84 \pm 0.13$ & $0.085 \pm 0.01$ & $10.1 \pm 0.40$ \\
\hline $150 \% \mathrm{~N}+(\mathrm{Fe}+\mathrm{Mo})$ & $473.46 \pm 5.23$ & $4.86 \pm 0.11$ & $0.145 \pm 0.01$ & $12.59 \pm 0.19$ \\
\hline F.Test & $* *$ & $* *$ & $* *$ & $* *$ \\
\hline LSD at $5 \%$ & 7.4651 & 0.0871 & 0.0147 & 0.2911 \\
\hline
\end{tabular}

*NRAA: Nitrate Reductase (NRA) Enzyme Activity

The average values of protein percentage (\%) in Jews mallow leaves as influenced by single application of nitrogen rates with foliar application of $\mathrm{Fe}+$ Mo combined together are showed in Tables 5 \& Fig. 2. The present data in Table $5 \&$ Fig. 2 there was a significant increase in protein percentage $(\%)$ recorded with the application of soil nitrogen fertilization at $(50,100,125$ and $150 \%)$ from the recommended dose. The highest value of protein percentage $(\%)$ was recorded with $150 \%$ of nitrogen fertilizer from recommended dose.

Nitrogen is an essential macronutrient for plants. It is an important component for the synthesis and formation of chlorophyll, enzymes, vitamins and proteins in plants, and is a central part of the essential photosynthetic molecules Marschner, (1995). Nitrogen fertilization leads to increases in vegetative, increases protein content of crops, enhances the metabolic processes that based on protein, improve fruit quality, enhances the growth of leafy vegetables. The increase in the protein is an expected result to the successive increase in nitrogen level in response to nitrogen fertilizer. These results are agreement with Abayomi et al., (2008) they found with increasing of NPK fertilizer application, increment in vegetative growth referring to role in activate and synthetic many enzymes in plant. Such enzymes act as catalyst for making materials such as protein and starch.

With regard to the effect of the foliar spraying with iron plus molybdenum with the same of nitrogen fertilization levels, data in Table 5 indicated the average values of protein percentage (\%) in Jews mallow leaves were significantly increase due to the foliar application of Fe and Mo comparing with those obtained from the same nitrogen fertilization levels in the absence of iron plus molybdenum in foliar way. The treatment of $150 \% \mathrm{RD}+$ (iron plus molybdenum) resulted in maximum amount of protein $(12.95 \pm 0.19 \%)$. While, the lowest values of protein percentage $(6.99 \pm 0.35 \%)$ were obtained from the control treatment.

As shown from Table 5 and Fig. 2, in spite of foliar application of $\mathrm{Fe}+$ Mo coupled with $\mathrm{N}$ rates under study led to sharp decreases in insoluble nitrogen forms $\left(\mathrm{NO}_{3}^{-}\right.$ and $\mathrm{NO}_{2}^{-}$) compared with an addition of $\mathrm{N}$ rates only, it resulted in increases the total nitrogen content in Jews mallow leaves. It can be concluded that $(\mathrm{Fe}+\mathrm{Mo})$ foliar spraying led to an increase in the activity of nitrate reductase (NRA) enzymes, consequently more reduction of $\mathrm{NO}_{3}-\mathrm{N}$ and $\mathrm{NO}_{2}-\mathrm{N}$ were happened resulted in producing nitrogen compound like protein. Such results were reported by Abd-Allah (2001). 


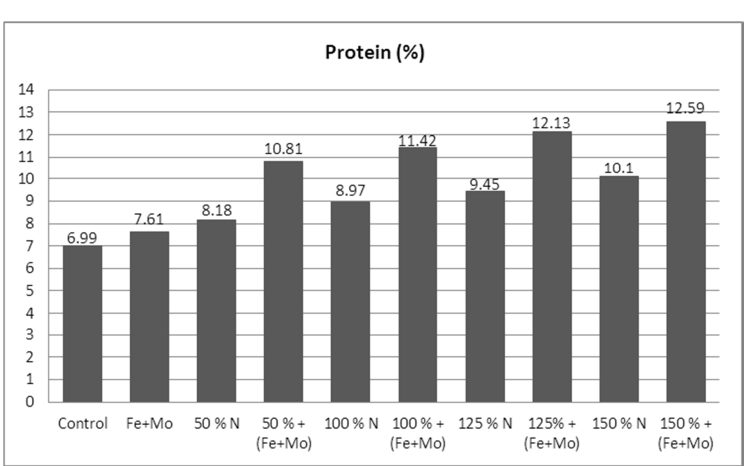

Fig. 2. Effect of different levels of $\mathbf{N}$-fertilization and foliar spraying with (Fe plus Mo) on protein \% in Jews mallow leaves plant during 2015/2016 season.

Level of vitamin C \& total carbohydrates \%

Results of Table 6 showed that; an application of nitrogen fertilizer rates significantly increased vitamin $\mathrm{C}$ content and total carbohydrates at marketing stage when the fertilization rate $\mathrm{N}$ increased from $50 \%$ up to $100 \%$ in single form without and with iron plus molybdenum over the control treatment. On the other hand, increased nitrogen fertilizer rates from 100 to $150 \% \mathrm{RD}$ in single form significantly decreased the average values of vitamin $\mathrm{C}$ content and total carbohydrates (\%) in leaves of Jews mallow.

Under current study, application of $\mathrm{Fe}+\mathrm{Mo}$ together as foliar spraying with the same nitrogen fertilization levels led to increase the average values of vitamin $\mathrm{C}$ contents and total carbohydrates (\%) in Jews mallow leaves comparing with those obtained from the same nitrogen fertilization levels in the absence of iron and molybdenum in foliar way. The maximum values of vitamin $\mathrm{C}$ content and total carbohydrates were $3.61 \pm 0.21$ $\mathrm{mg} / 100 \mathrm{~g}$ and $11.94 \pm 0.17 \%$ found in $(100 \% \mathrm{~N}$ and $\mathrm{Fe}+$ Mo) treatment. The lowest values were recorded for the control treatment. These results in accordance with the findings of Mozafar, (2005).

Table 6. Effect of levels of $\mathrm{N}$ fertilization, Fe + Mo as foliar way on Vitamin $\mathrm{C}$. $\mathrm{mg} 100 \mathrm{~g}^{-1}$ and total carbohydrates $\%$ contents of Jews mallow leaves plant during 2015/2016 season.

\begin{tabular}{lcc}
\hline Treatments & $\begin{array}{c}\text { Vitamin C } \\
\mathbf{m g ~ 1 0 0 g}^{-1} \mathbf{F . W}\end{array}$ & $\begin{array}{c}\text { Total Carbohydrates } \\
(\mathbf{\%})\end{array}$ \\
\hline Control & $1.09 \pm 0.14$ & $9.16 \pm 0.21$ \\
$\mathrm{Fe}+\mathrm{Mo}$ & $1.38 \pm 0.23$ & $9.47 \pm 0.17$ \\
$50 \% \mathrm{~N}$ & $1.65 \pm 0.15$ & $9.74 \pm 0.17$ \\
$50 \% \mathrm{~N}+(\mathrm{Fe}+\mathrm{Mo})$ & $2.83 \pm 0.13$ & $10.77 \pm 1.12$ \\
$100 \% \mathrm{~N}$ & $2.53 \pm 0.24$ & $10.74 \pm 0.15$ \\
$100 \% \mathrm{~N}+(\mathrm{Fe}+\mathrm{Mo})$ & $3.61 \pm 0.21$ & $11.94 \pm 0.17$ \\
$125 \% \mathrm{~N}$ & $2.25 \pm 0.19$ & $10.44 \pm 0.19$ \\
$125 \% \mathrm{~N}+(\mathrm{Fe}+\mathrm{Mo})$ & $3.44 \pm 0.25$ & $11.77 \pm 0.17$ \\
$150 \% \mathrm{~N}$ & $1.95 \pm 0.25$ & $10.11 \pm 0.19$ \\
$150 \% \mathrm{~N}+(\mathrm{Fe}+\mathrm{Mo})$ & $3.15 \pm 0.20$ & $11.37 \pm 0.12$ \\
\hline F.Test & $*$ & $* *$ \\
LSD at 5\% & 0.1812 & 0.3224 \\
\hline
\end{tabular}

Available nitrogen, phosphorus and potassium in the soil under study

With attention to results in Tables 7 showed different levels of $\mathrm{N}$-fertilizers effects, iron plus molybdenum as foliar application on $\mathrm{N}, \mathrm{P}$ and $\mathrm{K}$ soil available $\mathrm{N}, \mathrm{P}$ and $\mathrm{K}$ after harvest of Jews mallow. It can be observed that; these treatments were found significant effect on soil available $\mathrm{N}, \mathrm{P}$ and $\mathrm{K}$. The significantly highest available $\mathrm{N}, \mathrm{P}$ and $\mathrm{K}(87.04 \pm 1.22,7.96 \pm 0.28$ and $137.4 \pm 3.81 \mathrm{mg} \mathrm{kg}^{-1}$ ) were recorded by treatment $100 \%$ $\mathrm{RD}$ of $\mathrm{N}$ fertilization $+(\mathrm{Fe}+\mathrm{Mo})$ comparing with the control which recorded the lowest values. Increased availabilities of $\mathrm{N}, \mathrm{P}$, and $\mathrm{K}$ may maybe it is due to the rate of change in in soil nutrient which include mineralization, chemical complexation, decomposition adsorption or nutrient uptake by crops and soil organisms which led to altered ecosystem characteristics (Marrs, 1993). These results are compatible with Kamble and Kathmale, (2015) they found that $125 \% \mathrm{RD}$ of NPK was recorded the significantly highest available nitrogen, phosphorus to onion appears to be enhancing soil fertility.

Table 7. Soil availability of $\mathrm{N}, \mathrm{P}$ and $\mathrm{K}$ as affected by different levels of $\mathrm{N}$ fertilization and foliar application with Fe plus Mo.

\begin{tabular}{lccc}
\hline Treatments & $\mathbf{N ~ m g ~ k g}$ & $\mathbf{P ~ m g ~ k g}^{-\mathbf{1}}$ & $\mathbf{K ~ m g ~ k g}^{-\mathbf{1}}$ \\
\hline Control & $42.57 \pm 1.81$ & $4.23 \pm 0.28$ & $91.43 \pm 1.94$ \\
$\mathrm{Fe}+\mathrm{Mo}$ & $47.33 \pm 1.49$ & $4.61 \pm 0.27$ & $115.26 \pm 3.77$ \\
$50 \mathrm{Kg} / \mathrm{N}$ & $52.73 \pm 0.87$ & $5.45 \pm 0.25$ & $79.03 \pm 2.53$ \\
$50 \mathrm{Kg} / \mathrm{N}+(\mathrm{Fe}+\mathrm{Mo})$ & $71.77 \pm 1.64$ & $7.25 \pm 0.28$ & $103.73 \pm 3.92$ \\
$100 \mathrm{Kg} / \mathrm{N}$ & $67.45 \pm 1.94$ & $5.96 \pm 0.34$ & $97.5 \pm 3.81$ \\
$100 \mathrm{Kg} / \mathrm{N}+(\mathrm{Fe}+\mathrm{Mo})$ & $87.04 \pm 1.22$ & $7.96 \pm 0.28$ & $137.4 \pm 3.81$ \\
$125 \mathrm{Kg} / \mathrm{N}$ & $62.53 \pm 1.24$ & $6.38 \pm 0.39$ & $109.73 \pm 4.60$ \\
$125 \mathrm{Kg} / \mathrm{N}+(\mathrm{Fe}+\mathrm{Mo})$ & $83.16 \pm 0.87$ & $7.64 \pm 0.31$ & $128.5 \pm 3.60$ \\
$150 \mathrm{Kg} / \mathrm{N}$ & $58.22 \pm 1.77$ & $6.80 \pm 0.37$ & $84.66 \pm 3.72$ \\
$150 \mathrm{Kg} / \mathrm{N}+(\mathrm{Fe}+\mathrm{Mo})$ & $74.03 \pm 11.28$ & $4.97 \pm 0.33$ & $121.3 \pm 4.52$ \\
\hline F.Test & $* *$ & $* *$ & $* *$ \\
LSD at 5\% & 3.2222 & 0.2744 & 3.3394 \\
\hline
\end{tabular}




\section{CONCLUSION}

This study showed the possibility of obtaining a safe return of Jews mallow plant (Corchorus olitorius L.) by treating plants at the rate of $100 \%$ nitrogen from the recommended dose $\left(60 \mathrm{Kg} \mathrm{N} \mathrm{fed}^{-1}\right)$ in the presence of iron plus molybdenum at the rate of 250 and $75 \mathrm{mg} \mathrm{L}^{-1}$, respectively in the foliar way.

\section{REFERENCES}

Abayomi, Y., O. F. Ajibad and B. F. Saadudeen (2008). Growth and yield responses of cowpea (Vigna unguiculata (l) walp) genotypes to nitrogen fertilizer ( N.P.K) application in the southern guinea savanna of Nigeria. Asian Journal of plant sciences.,7(2):170-176

Abd-Allah, G. A. (2001). Effect of heavy nitrogen application on yield and chemical composition of some vegetable crops. Ph.D. Thesis, Soil, Dep. Fac. Agric. Mans. Univ. Egypt.

Abdelraouf, A. A. E (2016): The effects of nitrogen fertilization on yield and quality of spinach grown in high tunnels. Department of Natural Resources and Agricultural Engineering, Damanhur University, Egypt.

Ahmadi, H., V. Akbar Pour, F. Dashti and A. Shojaeian (2010). Effect of different levels of nitrogen on yield, nitrate accumulation and several quantitive attributees of five Iranian spinach. American Eurasian J. Agric. And Environ. Sci., 8(4): 468473.

Ahmed, A. H. H., M. K. Khalil and A. M. Farrag (2002). Nitrate accumulation, growth, yield and chemical composition of rocket (Eruca vesicaria subsp. sativa) plant as affected by NPK fertilization, kinetin and salicylic acid. Annals-Of-AgriculturalScience-Cairo; 47 (1): 1-26.

Ahmed, E.S.M., A. A. Elzaawely and M. B. El-Sawy (2011). Effect of the foliar spraying with molybdenum and magnesium on vegetative growth and curd yields in cauliflower (Brassica oleraceae var. botrytis L.). World Journal of Agricultural Sciences 7 (2): 149-156.

Aisha, H. A., M. Hafez, Asmaa, R. M. and M.R. Shafeek (2013). Effect of Bio and chemical fertilizers on growth, yield and chemical properties of spinach plant (Spinacia oleracea L.). Middle East Journal of Agriculture Research, 2(1): 16-20.

AOAC, (2007). Official Methods of Analysis. 18th Ed., International, Gaithersburg, MD.

Black, C. A. (1965). Methods of soil analysis. Part 2. Amer. Soci. of Agric. [NC] Publisher, Madison, Wisconsin.

Boink, A., Speijers, G. (2001). Health Effects of Nitrate and Nitrites, A Review. Acta Hortic, 563, 29-36.

Bremner, J.M. and Mulvaney, C.S. (1982). "Total nitrogen", In: A.L. Page, R.H. Miller and D.R. Keeny, (Eds.), Methods of Soil Analysis, American Society of Agronomy and Soil Science Society of America, Madison, pp. 1119-1123.

Chapman, H. D and Pratt, (1961): "Methods of soil analysis" Part 2 A. S. S. Madison Wisconsin.
Dewis, J., and F. Feritas, (1970): Physical and Chemical Methods of Soil and Water Analysis, FAO, Rome, soil Bulletin, No. 10.

Dubois, M., Gilles,K.A. Hamilton,J.K. Bebra P.A. and F. Smith (1956).Colorimetric methods for determination of sugars and related substances. Analyt. Chem., 28 (3): 350.

. El-Agrodi, W., El-Sirafi Z.M., Ahmed A.R., Baddour G.A (2001) Effect of heavy nitrogen application on nitrate contamination in lettuce plant at marketing stages. J. Agric. Sci. 26: 8263-8275.

EL-Aila, H.I., S.A.A EL-Sayed and A. A. Yassen, (2015). Response of Spinach Plants to Nanoparticles Fertilizer and Foliar Application of Iron. International Journal of Environment 4: 181-185.

El-Ghamry, A. M. (2010). Nitrate Accumulation as Affected by Nitrogen Fertilization and Foliar Application of Micronutrients in Rocket Plant. Molecular Environmental Soil Science at the Interfaces in the Earth's Critical Zone pp 103-109.

El-Sawah A. Nevein, and F. M. Gadallah, (2004). Response of spinach (Spinacia oleraceal) grown under different forms and rates of $\mathrm{N}$ fertilizer to foliar-feeding with Mo and Mn. 2- chemical constituents and nitrate accumulation. Egypt J. Appl. Sci. 19 (8): 95-118.

FAO. (2000). Guidelines and reference materials on integrated soil and nutrient management and conservation for farmers' field schools. Report AGL/MISC/27/2000. FAO, Rome.

Gomez, K. A., and Gomez, A. A. (1984). "Statistical Procedures for Agricultural Research". John Wiley and Sons, Inc., New York.pp:680.

Gulser, F. (2005). Effects of ammonium sulphate and urea on $\mathrm{NO}_{3}^{-}$and $\mathrm{NO}_{2}-$ accumulation, nutrient contents and yield criteria in spinach. Sci. Horti. $106: 330$ 340.

Hageman, R. H. and A. J. Reed, (1980). Methods in Enzymology. Vo. 69 Part C (Ed Anthony San Pietro) Academic Press New York P 270.

Hammad, S. A.; M. A. Abou-Seeda, A. M. El-Ghamry, and E. M. Selim, (2007). Nitrate accumulation in spinach plants by using $\mathrm{N}$-fertilizer types in alluvial soil. J. Applied Sci. Res., (6): 511-518.

International Organization for Standardization (ISO) (1995). "Soil quality: extraction of trace elements soluble in aqua-regia," ISO 11466, ISO, Geneva, Switzerland.

Jackson, M. L. (1967). Soil Chemical Analysis Advanced Course" Puble. By the auther, Dept. of Soils, Univ. of Wisc., Madison 6, Wiscensin, U.S.A.

Nasar, J and and Zahir Shah, Z. (2017). Effect of iron and molybdenum on yield and nodulation of lentil. Journal of Agricultural and Biological Science. vol. 12 , no. 11

Kheir, N. F.; Hanafy, A. A. H.; Abou El-Hassan, E. A. and Harb, E. M. Z. (1991). Physiological studies on the hazardous nitrate accumulation in some vegetables. Bull. Cac., of Agric. Univ., Cairo, 42 (2): 557-576.

Kosaka H, Imaizumi K, Imai K, Tyuma I (1979) Stoichiometry of the reaction oxyhemoglobin with nitrate. Biochim. Biophy. Acta 581: 184-188. 
Liu, C.W., Sung, Y., Chen, B.C. \& Lai, H.Y. (2014) Effects of nitrogen fertilizers on the growth and nitrate content of lettuce (Lactuca sativa L.). Int $J$ Environ Res Public Health, 11(4), 4427-4440.

Mahlangu, R. I. S.; M. M. Maboko, D. Sivakumar, P. Soundy and J. Jifon (2016): Lettuce (Lactuca sativa L.) growth, yield and quality response to nitrogen fertilization in a non-circulating hydroponic system. Journal of Plant Nutrition., 39 (12):1766-1775.

Mahmoud, A. R.; Hafez, M. M.; M.R. Shafeek, M. R. and Aisha, H. Ali, A. H. (2014). Growth, yield and leaf content of Jews mallow plant (Corchorus olitorius) by soil fertilizer with different level of compost manure and chemical fertilizer. Middle East Journal of Agriculture Research, 3(3): 543-548.

Marschner, H. (1995). Mineral Nutrition of Higher Plants, 2nd ed. Academic press. London. P. 196.

Mazumdar, B. C. and K. Majumder, (2003): Methods on physic-chemical Analysis of Fruits. Univ. Cokkege Agric. Calcutta Univ., 108-109.

Mozafar, A., (2005). Decreasing of $\mathrm{NO}_{3}$ and increasing the vitamin $\mathrm{C}$ contents spinach by a nitrogen deprivation method. J. Plant Foods Human Nutr., 49:155-162.

Olsen, S. R. and L. E. Sommers, (1982): Phosphorus. Pp. 403-130. Methods of soil Analyssi. Part2: Chemical and Microbiological properties. Am. Soc. of Agron., Inc. Madison, Wis, USA.

Peterburgski, A. V. (1986). "Hand Book of Agronomic Chemistry". Kolas Publishing House Moscow, (in Russian).pp.29-86.

Piper, C. S. (1950): Soil and plant analysis. Inter Science Publishers Inc. New York.

Qiu, W.; Z. Wang, C. Huang, B. Chen and R. Yang, (2014): Nitrate accumulation in leafy vegetables and its relationship with water. Journal of Soil Science and Plant Nutrition, 14 (4), 761-168.

Resende, G.M., Alvarenga, M.A.R., Yuri, J.E. \& Souza, R.J. (2010). Yield and postharvest quality of winter growing crisphead lettuce as affected by doses of nitrogen and molybdenum. Hortic Bras, 28(4), 441445 .
Ronaghi, A.; Y. Parvizi, and N. Karimian, (2002): Effect of nitrogen and manganese on the growth and chemical composition of spinach. Journal of Science and Tecnology of Agriculture and Natural Resources, 5 (4): 71-84.

Sadasivam, S. and A. Manickam, (1996): Biochemical Methods, second edition, New age inter. India.

Sakara, E. M. H. (2016): Effect of Nitrogen, Calcium and Selenium Nutrition on Chemical Composition and Nutrition Value of Spinach Plant (Spinacia Oleracea L.). Ph.D. Thesis, Soil, Dep. Fac. Agric. Mans. Univ. Egypt.

Salem, N. F. G (2009): Effect of different sources and levels of $\mathrm{N}$-fertilizers and foliar application of some micronutrients on nitrate accumulation in radish and parsley plants. M.Sc. thesis, Fac. Sci., Al-Azhar Univ.

Samra, I., S. Piliz and C. Ferdag, (2007). Antibacterial and antifungal activity of Corchorus.

Santamaria, P. (2006). Nitrate in vegetables, toxicity, content, intake and EC regulation. J Sci Food Agr, 86, 10-17.

Shaheen, A. M.; F. A. Rizk, E. H. A. El-Samad, and Z. S. A. El-Shal (2012). Growth, yield and chemical properties of spinach plants as influenced by nitrogen fertilizer forms and micro-elements foliar application. J. of Applied Sci. Res., (February):777785.

Singh, J. P. (1988): A rapid method for determination of nitrate in soil and plant extracts. Plant and soil. 110: 137-139

Tovihoudji, G. P; Djogbenou, D. P; Akponikpe, P.B; Kpadonou, E. Agbangba, C. E and dagbenonbakin, D. G (2015). Response of Jute Mallow (Corchorus olitorius L.) to organic manure and inorganic fertilizer on a ferruginous soil in North-eastern Benin. Journal of Applied Biosciences 92:8610 8619.

U.S. Salinity Laboratory Staff (1954): Diagnosis and Improvement of Saline and Alkali Soils. USDA Agric. Hand Book No. 60, Washington, D.C.

\footnotetext{
تأثير التسميد التيثروجيني و الرش الورقي بالحديا والموليبينوم على صفات الجودة والخواص الكيميائية لتبات

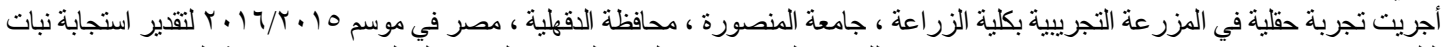

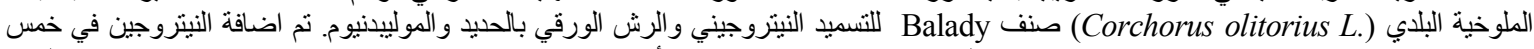

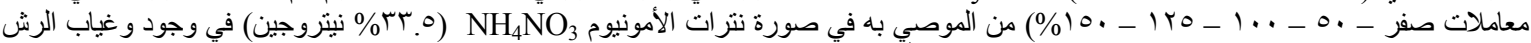

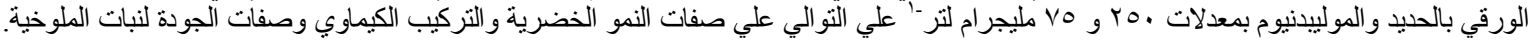

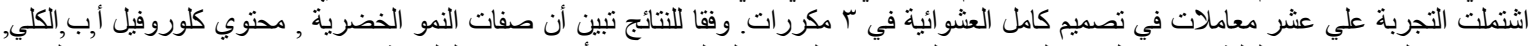

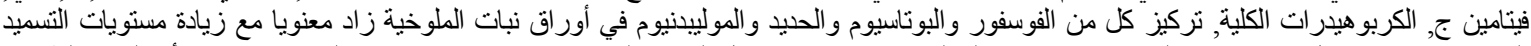

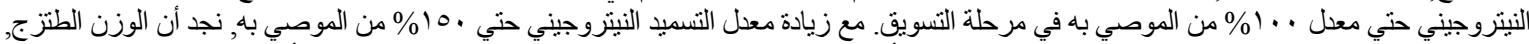

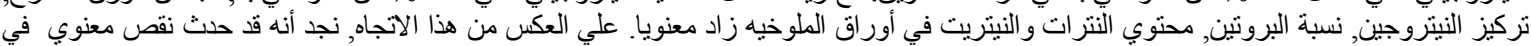

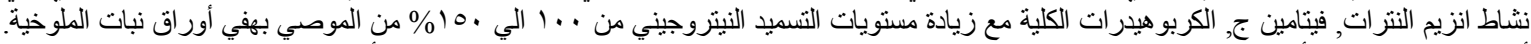

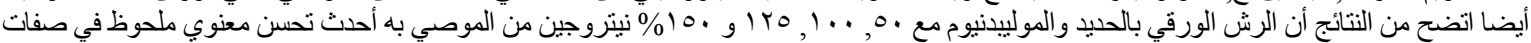

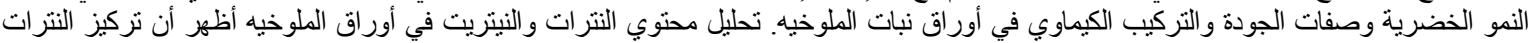

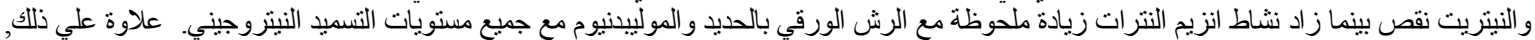

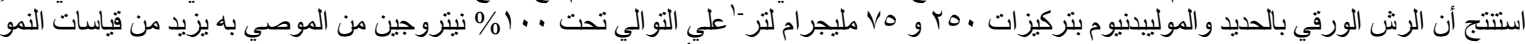

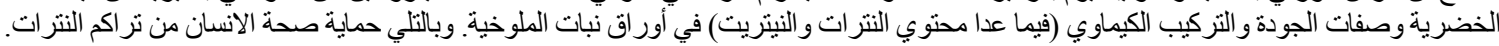

